\title{
(5)
}

\author{
AL-DZIKRA \\ Jurnal Studi Ilmu Al-Qur'an Dan Al-Hadits \\ http://ejournal.radenintan.ac.id/index.php/al-dzikra \\ Volume 12, No. 1, Juni Tahun 2018, Halaman 1 - 26 \\ DOI://dx.doi.org/10.24042/al-dzikra.v12i1.2926
}

\section{HISTORIOGRAFI PEMBUKUAN HADIS MENURUT SUNNI DAN SYI'AH}

\author{
Ahmad Paishal Amin \\ UIN Sunan Kalijaga Yogyakarta \\ muh.paishal.amin@gmail.com
}

\begin{abstract}
This paper describes the differences in historiography of the hadith bookkeeping between Sunni and Shiite groups. This division of Muslims into Sunni and Shiite groups has an impact on the differences in the history of hadith (hadith historiography). Sunnis have their own historiographic version of the hadith according to the literature they receive. Likewise with Shia. One of the factors that underlie these differences is because of the different interpretations of the history they received together. This difference in interpretation has an impact on differences in historical writing.
\end{abstract}

\section{Abstrak}

Tulisan ini memaparkan perbedaan historiografi pembukuan hadis antara kelompok Sunni dan Syi'ah. Perpecahan umat Islam ke dalam kelompok Sunni dan Syi'ah ini berdampak pada perbedaan dalam penulisan sejarah hadis (historiografi hadis). Sunni memiliki versi historiografi hadis sendiri sesuai dengan literatur yang mereka terima. Demikian juga halnya dengan Syi'ah. Salah satu faktor yang mendasari perbedaan tersebut adalah karena adanya perbedaan interpretasi (pemahaman) 
terhadap sejarah (baca: data) yang mereka lalui bersama. Perbedaan interpretasi ini berdampak pada perbedaan penulisan sejarah (historiografi).

Kata Kunci: Historiografi, Hadis, Sunni, Syi'ah, Interpretasi.

\section{A. Pendahuluan}

Perbedaan selalu terjadi dalam memahami, menginterpretasi dan menerima sejarah. Hal ini dikarenakan adanya perbedaan pengetahuan yang mereka alami dan perbedaan penginterpretasian terhadap apa yang mereka ketahui. Perbedaan ini terus muncul dalam berbagai masa dan tempat seiring berjalannya waktu karena faktor yang terus mempengaruhi pengetahuan tersebut berbedabeda. Seperti itu juga apa yang telah terjadi pada kelompok Sunni dan Syi'ah. Meski mereka berafiliasi pada agama yang sama dan Nabi yang sama, yaitu Islam dan Nabi Muhammad, tapi mereka berbeda dalam memahami sejarah, khususnya sejarah pembukuan hadis. Padahal sejarah yang mereka alami dari semenjak Nabi Muhammad wafat hingga munculnya kelompok-kelompok dalam Islam (Sunni dan Syiah) adalah sama.

Perbedaan tersebut nampak dalam penulisan sejarah yang terdapat dalam sumber-sumber literatur masing-masing. Dalam bidang hadis, literatur-literatur Sunni memaparkan sejarah dari penulisan hadis hingga pembukuan dimulai dari masa 'Umar bin 'Abd al-Aziz pada abad kedua hijriah. ${ }^{1}$ Hal tersebut dikarenakan berbagai faktor yang melatar-belakanginya. Sementara menurut Syi' ah, penulisan hadis sudah ada semenjak Nabi Muhammad SAW masih hidup. ${ }^{2}$ Hal tersebut mereka buktikan dengan adanya mushaf

${ }^{1}$ Al-Bukhāri, Kitab al-'Ilm, bab Kaīf Yuqbad al-'Ilm, Sahih al-Bukhari, hadis: 1. Lihat juga 'Ali al-Sāyis, Tārìkh al-Fiqh al-Islāmì (Beirut: Dār al-Kutub al-Ilmiah) h.101. Abdurrahman bin Abi Bakr Jalaluddin al-Suyuṭi, Tadrīb alRāwī fì Syarh Taqrīb al-Nawāwī, j. 1 (Beirut: Dār al-Fikr, 1988 M/1409 H), h. 90.

${ }^{2}$ Al-Ṭuhranīy, al-Zarī'ah, j. 2 (Beirut: Dār al-Aḍwa, 1403H), h. 306. Muhsin al-Amin, A'yān al-Sȳ̄'ah, j. 1 (t.t: Dār al-Ta'āruf li al-Maṭbu'at, t.t), h. 330-338. 
'Ali yang menurut mereka masih utuh dan terus menjadi pegangan bagi kelangsungan ajaran mereka.

Di sini penulis berusaha mengkaitkan historiografi pembukuan hadis Sunni dan Syi'ah dengan tahapan-tahapan penelitian sejarah hingga historiografi. Sehingga perbedaan yang terjadi antara mereka bisa kita pahami dan kita maklumi untuk kemudian menjadi tambahan khazanah pengetahuan Islam.

\section{B. Tahapan Menuju Historiografi}

Dalam metodologi sejarah, untuk sampai kepada tahapan historiografi, ada 4 langkah yang harus dilakukan: heuristik, verifikasi, interpretasi, dan historiografi. ${ }^{3}$

1. Heuristik (Pengumpulan Sumber)

Heuristik adalah usaha sejarawan dalam rangka memilih suatu subjek dan mengumpulkan informasi mengenai subjek. Heuristik sejarah pada hakikatnya sama dengan kegiatan bibliografis yang lain dalam hal buku-buku yang tercetak, hanya saja sejarawan harus mempergunakan banyak materi yang tidak terdapat di buku-buku. Untuk mengatasi kebingungan atas banyaknya material-material yang didapat, maka sejarawan harus selektif dalam memilih sumber. Sumber yang dikumpulkan harus sesuai dengan jenis sejarah yang akan ditulis. Sumber tersebut, menurut bahannya, terbagi dua: tertulis (dokumen) dan tidak tertulis. Yang tidak tertulis ini juga terbagi kepada dua yaitu artifak (foto, bangunan, dll) dan lisan.

2. Verifikasi (Kritik Sumber)

Verifikasi terbagi dua: otentisitas atau kritik ekstern dan kredibilitas atau kritik intern. Verifikasi otentisitas adalah sebuah usaha untuk mengetahui keaslian sumber yang telah didapat, sedangkan verifikasi kredibilitas adalah upaya untuk memastikan bahwa sumber yang didapat tersebut adalah terpercaya.

${ }^{3}$ Kuntowijoyo, Pengantar Ilmu Sejarah (Yogyakarta: Bentang Pustaka, 2005), h. 99. Lihat juga Herlina Lubis, Sejarah Perkembangan Islam di Jawa Barat (Jawa Barat: Yayasan Masyarakat Sejarawan Indonesia, 2011), h. 15. 


\section{Interpretasi: Analisis dan Sintesis}

Interpretasi sering dianggap sebagai biang subjektifitas. Hal itu dikarenakan sejarah tanpa sejarawan yang melakukan interpretasi adalah "tidak ada", sementara sejarawan bisa jadi tidak jujur dalam mencantumkan data dan keterangan yang dia peroleh. Karena itu pulalah interpretasi terhadap sejarah kadang tidak sama dan berubah-ubah. Dalam melakukan interpretasi setidaknya ada dua tahapan yang harus dilewati: analisis dan sintesis. Analisis berarti menguraikan sumber yang diperoleh setelah melalui uji verifikasi, sedangkan sintesis berarti manyatukan sumber-sumber yang dianalisis tadi dengan memberikan kesimpulan akhir. Dalam interpretasi ini, baik analisis maupun sintesis, para sejarawan bisa berbeda pendapat. Perbedaan interpretasi ini dalam kajian ilmiah dianggap sah meskipun data yang diperoleh sama.

4. Historiografi (Penulisan)

Tahapan akhir dari sebuah penelitian terhadap sejarah adalah penulisan (historiografi). Penulisan sejarah ini adalah puncak dari berbagai tahapan penelitian sejarah yang telah dilalui, karena apa yang telah dituliskan itulah (histoire-recite) yang bernama "sejarah" sebagaimana yang dikisahkan, dari hasil memahami sejarah sebagaimana terjadinya (histoire-realite).

\section{Historiografi Perumusan Metodologi Kritik Hadis}

\section{Menurut Perspektif Literatur Sunni}

Berbagai hadis Nabi yang termaktub di kitab-kitab hadis sekarang ini, asal mulanya adalah hasil kesaksian para sahabat Nabi terhadap perkataan, perbuatan, taqrir, dan atau hal-ihwal Nabi. apa yang disaksikan oleh sahabat itu lalu disampaikannya kepada orang lain. Orang lain yang menerima riwayat hadis itu mungkin saja berstatus sebagai sahabat, al-mukhadramin ${ }^{4}$, atau al-tabi'in. Al-

${ }^{4}$ Al-Mukhadramin adalah orang-orang yang hidup pada masa Nabi saw. masih hidup namun tidak sempat bertemau dengan beliau. Mereka di antaranya adalah Al-Ahnīf ibn Qoids, al-Aswād ibn Yazīd, Sa'ad ibn Iyyas, 'Abdullāh ibn Ukain, 'Amr ibn Matmūn, atau Muslim al-Khoulan̄̄, dan al-Najāsyi (raja negeri Habasyah). 'Abd al-Qadīr bin 'Umar al-Bagdādi, Khazanah al-Adab wa Lubb Lubāb Lisān al- 'Arab, j. 1 (Kairo: Maktabah al-Khānizī, 1418 H), h. 268. 
Mukhadramin dan al-Tabi' in yang menerima riwayat hadis tadi lalu menyampaikan hadis itu kepada al-Tabi'in dan atau atba al-Tabi'in (generasi setelah Tabi'in), dan demikian seterusnya. Sehingga hadis itu akhirnya sampai kepada para periwayat yang melakukan kegiatan-kegiatan penghimpunan hadis. Buah karya para penghimpun hadis ini (al-mukharrij) itulah yang menjadi sumber pengetahuan dan rujukan hadis pada zaman berikutnya hingga sekarang.

Cara periwayat memperoleh dan menyampaikan hadis pada zaman Nabi tidaklah sama dengan yang dilakukan pada zaman sahabat Nabi. Demikian juga periwayatan pada zaman sahabat tidak sama dengan periwayatan pada zaman sesudahnya. Periwayatan hadis pada zaman Nabi lebih terbebas dari syarat-syarat tertentu bila dibandingkan dengan periwayatan pada zaman sesudahnya. Hal ini disebabkan karena pada zaman Nabi selain tidak ada bukti yang pasti tentang telah terjadinya pemalsuan hadis, juga pada zaman itu seseorang akan lebih mudah melakukan peremiksaan sekiranya ada hadis yang diragukan kesahihannya. Makin jauh jarak waktu dari masa hidup Nabi, makin sulit pengujian kebenaran suatu hadis.

Berikut cara periwayatan hadis Nabi menurut Sunni:

a. Periwayatan Hadis pada Zaman Nabi

Hadis yang diterima oleh para sahabat sangat cepat tersebar di masyarakat. Karena para sahabat umumnya sangat berminat untuk untuk memperoleh hadis Nabi dan kemudian menyampaikannya kepada orang lain. Hal ini terbukti dengan beberapa pengakuan para sahabat Nabi sendiri, misalnya sebagai berikut:

Umar bin al-Khattab telah membagi tugas dengan tetangganya untuk mencari berita yang berasal dari Nabi. kata 'Umar, bila tetangganya hari ini menemui Nabi, maka 'Umar pada esok harinya menemui Nabi. Siapa yang bertugas menemui Nabi dan memperoleh berita yang berasal atau berkenaan dengan Nabi, maka dia segera menyampaikan berita itu kepada yang tidak bertugas. Dengan demikian, para sahabat Nabi yang kebetulan sibuk tidak sempat menemui nabi, mereka tetap juga dapat memperoleh hadis dari sahabat yang sempat bertemu dengan Nabi. 
Sebagaimana yang Malik ibn al-Ḥuwairis nyatakan dalam sebuah hadis:

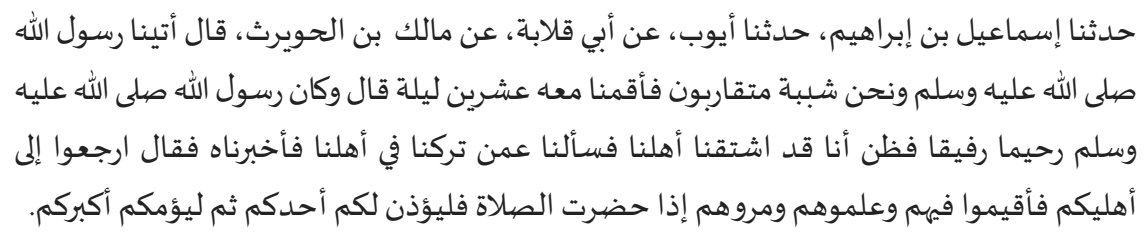

"Saya (Malik ibn al-Huwairis) menyatakan dalam satu rombongan kaum saya datang kepada Nabi saw. Kami tinggal di sisi beliau selama dua puluh malam. Beliau adalah seorang penyayang dan akrab. Tatkala beliau melihat kami telah merasa rindu kepada para keluarga kami, beliau bersaba: "Kalian pulanglah, tinggallah bersama keluarga kalian, ajarlah mereka, dan lakukan shalat bersama mereka. Bila masuk waktu shalat, hendaklah salah satu dari kalian melakukan azan, dan hendaklah yang tertua bertindak sebagai imam.."

Sejarah mencatat bahwa Nabi Muhammad Saw. banyak memiliki penulis. Sebagian dari mereka ada yang menulis wahyu dan sebagian yang lain ada yang mencatat perjanjian-perjanjian dan surat-surat Nabi Saw. Karena itu banyak dokumen-dokumen yang ditulis di masa beliau ditemukan oleh para sejarawan-sejarawan yang tertarik dengan isu Islam. Di samping referensi-referensi yang bersifat historis, sebagian dokumen terhimpun dalam dua kitab: Makātib al-Rasūl dan Majmu'ah al-Wasāiq al-Siyāsah. Beberapa dari sahabat, bahkan lebih dari 50 orang, juga mencatat hadis-hadis Nabi dengan motivasi tersendiri dengan media-media yang mereka miliki.

Beberapa penulis hadis di kalangan sahabat yang terkenal adalah: 'Ali bin Abi Thalib, 'Abdullah bin 'Amr bin Ash, Jabir bin 'Abdullah al-Anșari dan 'Abdullah bin 'Abbas. Ada beberapa dari mereka yang tersisa dan ditemukan, kemudian dimanfaatkan oleh orang-orang pasca mereka. ${ }^{6}$

${ }^{5}$ Bukhari, Kitab al-Da'awāt: 6008. Șaḥih Muslim, Kitab al-Żikr wa alTaubah wa al-Istigfar: 2706

${ }^{6}$ Al-Khațib al-Bagdadi, Taqyīd al- 'Ilm (Dār al-Istiqāmah, 2011), h. 32. 
Dalam beberapa riwayat, Nabi Saw. beberapa kali mewasiatkan para sahabatnya untuk menulis hadis. ${ }^{7}$ Salah satu sabda beliau Saw. berbunyi "tersisanya satu halaman dari seorang mukmin yang berisi suatu ilmu (dari perkara agama) akan menghalanginya dari api neraka." ${ }^{8}$ Bahkan dalam riwayat lain, saat Nabi Saw. ingin meninggal pun sempat ingin menuliskan sebuah wasiat namun dihalang oleh sebagian sahabat yang lain dengan alasan tertentu. ${ }^{9}$ Meskipun banyak bukti yang menunjukkan bahwa Nabi Saw. membolehkan penulisan hadis, namun sebagian ahli hadis dari kalangan Ahli Sunnah lebih memilih riwayat yang datang dari Abu Sa'id al-Khudri, Abu Hurairah dan Zaid bin S|abit yang menyatakan bahwa Nabi Saw. pada suatu ketika tidak menyetujui penulisan hadis dan bahkan melarang sahabatnya untuk menulis hadis-hadis tersebut. ${ }^{10}$ Meski begitu, para peneliti Ahlu Sunnah menganggap lemah riwayat yang datang dari Abu Hurairah dan Zaid bin S|abit. ${ }^{11}$ Sedangkan yang berkenaan dengan riwayat Abu Sa'id al-Khudri, beberapa 'ulama juga berbeda pendapat tentang mauquf dan marfu'nya. ${ }^{12}$ Meski jika kita anggap hadis ini marfu', ia juga masih memiliki problem dari sisi sanad dan teksnya, sehingga tidak bisa disimpulkan dengan cepat bahwa Nabi Saw tidak menyetujui penulisan hadis. Menurut ulama Ahlu Sunnah yang meyakini kesahihan hadis riwayat Abu Sa'id al-Khudri ini, mereka menyelesaikan kontradiksi riwayat perintah penulisan dan larangan penulisan ini biasanya dengan argumen "menggunakan kaedah naskh" atau "kekhususan khitab."13

${ }^{7}$ G.H.A. Juynboll, Kontroversi Hadits di Mesir (Bandung: Mizan, 18901960), h. 73.

${ }^{8}$ Muhammad Baqir al-Majlisi, Bihār al-Anwār: al-Jāmi'ah li Durari Akhbār al-Aimmah al-Aṭar, j. 2 (Beirut: Mansyurat Muassisah al-A'lamy li alMaṭu'at: 2008), h. 144.

${ }^{9}$ Muhammad bin Isma'il al-Bukhari, Șahih al-Bukhari, j. 1, h. 37.

${ }^{10}$ Al-Khatib al-Bagdadi, Taqyīd al-'Ilm ..., h. 29-35.

${ }^{11}$ Muhammad Mușțafa al-A'ẓami, Dirāsat fi al-Ahādis al-Nabaw̄̄ wa Tārīkh Tadwīnih, j. 1 (al-Maktab al-Islamī, 1400 H/1980 M), h. 78.

12 Muhammad 'Ajjaj al-Khațib, al-Sunnah Qabl al-Tadwin (Maktabat Wahbah: 1408 H/1988 M), h. 306.

13 Muhammad Babul 'Ulum, Merajut Ukhuwah, Mengenal Syi'ah (Bandung: Penerbit Marja, 1428/2008), h. 136. Untuk memahami problematika 


\section{b. Penulisan hadis pasca Wafatnya Nabi saw. (masa sahabat)}

Meski terdapat hadis Nabi Saw. yang membolehkan penulisan hadis pada masanya dan meski beberapa sahabat telah menulis hadis dengan seizin beliau, namun pada masa Khalifah alRasyidin, terutama pada masa tiga khalifah pertama, terdapat pelarangan penukilan dan penulisan hadis Nabi saw.

Di masa sahabat, di antara mereka ada yang melakukan pelarangan penulisan hadis dan ada pula yang membolehkannya. Pembolehan penulisan hadis lebih nampak pada masa pelarangan hadis sudah tidak ada lagi. Namun sebelumnya, larangan tersebut begitu gencar dikampanyekan dengan alasan utamanya adalah khawatir tercampurnya hadis tersebut dengan al-Qur'an. Di antara larangan tersebut dikemukakan dengan beberapa alasan sebagai berikut:

1. Kekhawatiran tercampurnya al-Qur'an dengan hadis Nabi Saw. dan kekhawatiran tidak ada perhatian terhadap al-Qur'an karena sibuk dengan yang lain.

Diriwayatan oleh Urwah bin Zubair bahwa 'Umar bin alKhatthab suatu ketika hendak menulis sunnah-sunnah Nabi saw. Ia kemudian meminta pendapat para sahabat tentang hal tersebut. Para sahabat memberi isyarat agar ia menulis hadis-hadis tersebut. Maka mulailah ia beristikharah terkait penulisan sunnah-sunnah tersebut selama sebulan. Pada suatu hari, ia bangun pagi dan tampaknya Allah memberikan kemantapan dalam dirinya. Ia berkata: "Sesungguhnya saya hendak menulis sunnah-sunnah Rasulullah Saw., namun saya teringat suatu kaum sebelum kalian yang membuat tulisan. Mereka terus-menerus menulis dan meninggalkan Kitab Allah. Dan aku, demi Allah, tidak akan mencampur sesuatu apapun dengan Kitab Allah selama-lamanya."14 Sehingga menurut satu riwayat dari Malik bin Anas, 'Umar tidak mau menulis sunnah dan ia berkata: "Tidak ada tulisan selain Kitab Allah."15

penulisan hadis ini bisa dilihat juga dalam buku Jalaluddin Rakhmat, Rekayasa Sosial, yang diterbitkan oleh Rosda, Bandung.

${ }^{14}$ Yusuf bin 'Abdillah al-Namry al-Qurțubi, Jami' al-Bayān al-'Ilm wa Faḍlih, j. 1 (al-Mamlakah al-Sa'ūdiyyah al-‘Arabiyyah, 1994 M/1414 H), h. 64.

${ }^{15}$ Ibid., h. 64. 
Hal yang dikhawatirkan oleh 'Umar dari penulisan sunnah ini adalah kaum muslimin terus-menerus mengkaji selain alQur'andan mengabaikan Kitab Allah. Oleh karena itu, 'Umar melarang para sahabat menyimpan tulisan lain bersama Kitab Allah. Ia sangat menentang orang yang menyalin tulisan Nabi Daniel, dan pasti memukul orang yang melakukannya. Kepada orang yang menulisnya, ia berkata: "Pergilan dan hapuslah tulisan itu. Jangan membaca tulisan itu dan jangan pula membacakannya kepada seseorang. Jika saya mendengar informasi bahwa engkau membacanya atau membacakannya kepada orang lain, niscaya saya akan menghukum kamu."16

2. Cukupnya al-Qur'an sehingga tidak ada kebutuhan terhadap hadis Nabi Saw.

Diceritakan dalam satu riwayat dari 'Abdullah bin Mas'ud bahwa ia tidak mau menerima tulisan hadis. Diriwayatkan dari 'Abdurrahman bin al-Aswad dari ayahnya ia berkata: "Alqamah datang dengan membawa tulisan dari Mekkah atau Yaman, yaitu lembaran berisi hadis-hadis tentang Ahlul Bait Rasulullah saw. Kemudian kami meminta izin masuk ke rumah 'Abdullah bin Mas'ud dan menemuinya. 'Alqamah berkata: "Kemudian kami menyerahkan lembaran itu kepadanya. Lalu ia (Ibn Mas'ud) memanggil seorang perempuan budaknya dan meminta bejana berisi air. Kami berkata kepadanya: "Hai Abu 'Abdurrahman (Ibn Mas'ud), lihatlah lembarang itu. Isinya hadis yang bagus-bagus." "Alqamah berkata: "Kemudian ia merendam lembaran itu ke dalam air di bejana dan berkata dengan mengutip ayat al-Qur'an: "Kami menceritakan kepadamu kisah yang paling baik dengan mewahyukan al-Qur'ankepadamu (Q.S. Yusuf: 3)." Hati adalah bejana maka penuhilah ia dengan al-Qur'andan jangan kamu memenuhinya dengan selainnya."17

Dalam hal ini terdapat riwayat yang menegaskan bahwa di antara isi lembaran itu terdapat perkataan Abu Darda' dan kisah-

${ }^{16}$ Khațib al-Bagdadi, Taqyīdu al-'Ilm ..., h. 50.

${ }^{17}$ Ibid., h. 54. Riwayat lain juga menyebutkan bahwa Ibn Mas'ud melarang sebagian sahabat yang hendak menulis perkataannya. Lihat Sunan alDārīmī, j. 1..., h. 125. 
kisahnya. ${ }^{18}$ Dalam satu riwayat yang lain salah seorang perawi berkata: "Ternyata lembaran itu berasal dari Ahlul Kitab. Oleh karena itu Ibn Mas'ud tidak mau melihatnya."19

Kita tidak bisa memastikan bahwa isi lembaran itu adalah kisah atau sesuatu yang berasal dari Ahlul Kitab karena terdapat riwayat yang tegas dari al-Aswad bin Hilal bahwa ia berkata: “"Abdullah bin Mas'ud diberi lembaran yang berisi suatu hadis. Kemudian ia meminta air dan menghapus isinya, lalu memerintahkan agar lembaran itu dibakar. Ia berkata: "Saya berharap Allah mengingatkan saya akan seseorang yang mengetahui lembaran itu. Demi Allah, seandainya saya mengetahui bahwa lembaran itu berada di kawasan India niscaya saya akan pergi ke sana. Karena tulisanlah, Ahlul Kitab sebelum kalian ini dibinasakan. Mereka membuang Kitab Allah ke belakang punggung mereka, seakan-akan mereka tidak mengetahuinya."20 Tindakan Ibn Mas'ud itu menunjukkan bahwa ia khawatir masyarakat luas sibuk menulis al-sunnah dengan meninggalkan al-Qur'an.

Suatu ketika 'Ali berpidato di hadapan umum lalu berkata: "Saya tidak menginginkan dari setiap orang yang memiliki tulisan kecuali ia menariknya dan menghapusnya. Manusia itu akan binasa jika mereka mengikuti ucapan 'ulama mereka, tetapi meninggalkan kitab Tuhan mereka."21

3. Mencegah terjadinya perselisihan di kalangan kaum muslimin

Ibnu 'Abbas berkata: "Sesungguhnya kami tidak menulis ilmu dan tidak pula menuliskannya untuk orang lain." 22 Diriwayatkan dari Sa'id bin Zubair dari Ibnu 'Abbas bahwa ia

\footnotetext{
${ }^{18}$ Khațib al-Bagdadi, Taqyīdu al-'Ilm ..., h. 54-55.

${ }^{19}$ Yusuf bin 'Abdillah al-Namrī al-Qurțubī, Jami' al-Bayān..., h. 66; Sunan al-Dārimi, j. 1, h. 124.

${ }^{20} I b i d$., h. 65. Riwayat yang sama disebutkan dalam Sunan al-Dārìmī sebagaimana berikut: "Seandainya lembaran itu berada di kawasan wilayah Handāriyah-suatu tempat yang jauh Dari Kufah-niscaya saya akan mendatanginya sekalipun dengan berjalan kaki.” Lihat Sunan al-Dārīmī, j. 1, h.
} 124.

${ }^{21}$ Ibid., 63.

${ }^{22} I b i d .$, 65. Lihat juga Khațib al-Bagdadi, Taqyīdu al-'Ilm, h. 42. 
melarang penulisan ilmu dan berkata: "Orang-orang sebelum kamu tersesat karena tulisan-tulisan." 23

Abu Musa tidak menyukai anaknya menulis hadits darinya karena khawatir ia menambah atau menguranginya dan ia menghapus apa yang ditulisnya dengan air. ${ }^{24}$ Dalam riwayat lain ia berkata: "Sesungguhnya Bani Israel menulis suatu kitab. Mereka mengikutinya dan meninggalkan kitab Taurat."25

4. Kekhawatiran menyandarkan kesalahan/kekeliruan kepada Nabi saw.

Suatu ketika Zaid bin S|abit melarang ketika Marwan bin alHakam hendak menulis hadis darinya. Zaid berkata: "Mungkin segala sesuatu (hadits) yang saya sampaikan kepadamu (sebenarnya) tidaklah seperti yang saya sampaikan kepadamu."26 Dalam riwayat lain dikatakan bahwa Zaid bin S|abitberkata: "Rasulullah Saw. memerintahkan kami agar kami tidak menulis sesuatu dari hadis beliau." 27

5. Peristiwa pembakaran dan penghapusan terhadap tulisan-tulisan

Suatu ketika 'Umar berpidato di depan orang banyak. Ia berkata: "Wahai manusia, saya telah mendapatkan berita bahwa kalian memiliki tulisan-tulisan. Tulisan yang paling dicintai oleh Allah adalah tulisan yang paling benar. Maka janganlah seseorang di antara kalian memiliki tulisan kecuali ia menyerahkannya kepadaku yang kemudian tulisan itu akan saya nilai." Para pendengar mengira bahwa 'Umar akan melihat tulisan-tulisan itu lalu mengoreksinya sehingga tidak ada lagi kesalahan. Maka mereka pun menyerahkan tulisan-tulisan mereka. Ternyata, 'Umar membakar tulisan-tulisan itu lalu berkata: "(Ini adalah) suatu kebohongan seperti kebohongan Ahlul Kitab."28

Umar juga mengirim surat ke berbagai kota yang isinya sebagai berikut: "Barang siapa memiliki suatu tulisan maka

${ }^{23}$ Ibid., 65. Lihat juga Khațib al-Bagdadi, Taqyīdu al- 'Ilm, h. 43.

${ }^{24}$ Al-Ramahurmuzi, al-Muhaddis al-Fāṣil, j. 4 (Naskah Damaskus), h.

6.

${ }^{25}$ Khațib al-Bagdadi, Taqyīdu al-'Ilm ..., h. 56.

${ }^{26}$ Yusuf bin 'Abdillah al-Namri al-Qurthubi, Jami' Bayan ..., h. 65.

${ }^{27}$ Khatib al-Bagdadi, Taqyidu al-'Ilm..., h. 35.

${ }^{28}$ Ibid., h. 52. 
hendaklah ia menghapusnya." Semua itu menunjukkan kekhawatiran "Umar bahwa Kitab Allah akan disia-siakan atau Kitab Allah diserupakan dengan tulisan lain. 'Umar sendiri tidak mau pendapatnya ditulis dan menginginkan pendapatnya dihapus. Ketika usianya telah lanjut, ia memerlukan seorang tenaga medis. Setelah diberitahu bahwa ajalnya sudah dekat, ia memanggil putranya dan berkata: "Hai 'Abdullah bin 'Umar, peganglah bahuku." Sekiranya Allah menghendaki ia dapat mengucapkan apa yang ada di dalam mulutnya, niscaya akan terucapkan. Ibnu 'Umar berkata kepadanya: "Cukuplah saya yang menghapusnya." "Umar menjawab: "Tidak. Demi Allah. Tidak boleh ada yang menghapusnya selain diri saya." Kemudian ia menghapusnya dengan tangannya sedangkan di dalam tulisan itu masih ada ketentuan hak waris bagi kakek. ${ }^{29}$

Menukil dari pendapat al-Khatib al-Bagdadi terkait ketidaksukaan para sahabat dalam menulis hadis, beliau berkata: "Sesungguhnya ketidaksukaan para penulis pada masa-masa awal Islam adalah karena mereka tidak rela Kitab Allah diserupakan dengan yang lainnya, atau tidak rela manusia menekuni selain alQur'an yang membuat terabaikannya al-Qur'an. Dilarang mengambil kitab (tulisan-tulisan) terdahulu karena tidak diketahui mana tulisan yang benar dan mana tulisan yang salah, sedangkan alQur'an telah mencakup semuanya. Dan, larangan menulis ilmu pada masa-masa awal Islam disebabkan sedikitnya jumlah orang yang berilmu pada masa itu dan orang yang bisa membedakan antara wahyu dan bukan wahyu. Karena mayoritas bangsa Arab tidak memahami agama dan tidak bergaul dekat dengan 'ulama yang 'arif, mereka menambahkan hal-hal yang mereka temukan dalam lembaran-lembaran tulisan ke dalam al-Qur'an dan meyakininya sebagai firman Allah." 30

Sedang para peneliti beranggapan bahwa tidak satupun alasan di atas menjadi sebab utama pelarangan penukilan dan penulisan hadis. Namun pelarangan tersebut lebih berhubungan

${ }^{29}$ Muhammad bin Sa'd al-Hasyimi, Tabaqat Ibn Sa'ad, j. 3 (Beirut: Dār al-Kutub al-'Ilmiah, 1410 H/1990 M), h. 247.

${ }^{30}$ Khatib al-Bagdadi, Taqyidu al-'Ilm..., 57. 
dengan fenomena politik pada masa tersebut. Di antara target dari larangan tersebut adalah melenyapkan hadis-hadis Nabi Saw. yang berkenaan dengan keutamaan dan keburukan bagi seseorang. ${ }^{31}$ Para peneliti tersebut menyodorkan bukti dengan menyatakan bahwa penukilan riwayat-riwayat tentang hukum atau fiqih saat itu tidak begitu sensitif. ${ }^{32}$

Dalam menghadapi pelarangan ini, reaksi para sahabat dan Tabi'in pun berbeda-beda. Sebagian dari mereka meninggalkan penukilan dan penulisan hadis Nabi saw ini. Sebagian lagi lebih memilih hanya mengingat hadis-hadis tersebut dan menolak untuk menulisnya, bahkan melenyapkan hadis-hadis yang mereka miliki. Dan sebagian yang lain memilih untuk tetap bertahan dan melanjutkan penukilan dan penulisan hadis ini. ${ }^{33}$ Penulisan hadis ini lebih jelas nampak ketika pelarangan penulisan hadis tersebut telah dicabut setelah beberapa periode berlalu, terlebih setelah al-Qur'an dihimpun dalam mushaf-mushaf dan dikirim ke berbagai wilayah Islam. ${ }^{34}$ Sebagaimana yang dikatakan al- Khatibal-Bagdadi: "Ketika kekhawatiran tersebut telah hilang dan terdapat kebutuhan untuk menulis ilmu maka penulisan ilmu tidaklah dianggap tabu, seperti halnya para sahabat tidak menolak penulisan tasyahhud. Tidak ada beda antara tasyahhud dan ilmu-ilmu lain selain tasyahhud, dalam arti semuanya bukanlah al-Qur'an. Dan para sahabat menuliskan ilmu dengan hati-hati sebagaimana ketidaksukaan mereka (untuk menulis ilmu) juga karena sikap kehati-hatian. $^{35}$

\footnotetext{
${ }^{31}$ Hasyim Ma'ruf al-Husaini, Dirāsāt fì al-Hadis wa al-Muhaddisīin
} (Beirut: Dār al-Ma'arif, tt), h. 2.

${ }^{32}$ Sebagaimana yang diriwayatkan oleh Ibn Kasir dalam kitabnya yang mengutip Dāri 'Umar: أقلو الرواية عن رسول الله (ص) إلا فيما يعمل به Lihat Ibn Kas̄ìr, alBidāyah wa al-Nihāyah, j. 4 (Beirut: Maktabat al-Ma'arif, 1414 H/1990 M), h. 110.

${ }^{33}$ Abdurrahman bin Abi Bakr Jalaluddīn al-Suyuți, Tadrib al-Rāwi fì Syarḥ Taqrīb al-Nawāwi, j. 2 (Beirut: Dār al-Fikr, 1988 M/1409 H), h. 61.

34 'Ajaj al-Khatib, Hadis Nabi Sebelum Dibukukan, trans. AH. Akron Fahmi (Jakarta: Gema Insani Press, 1999), h. 358.

${ }^{35}$ Khatib al-Bagdadi, Taqyidu al-'Ilm..., h. 94. 


\section{c. Pembukuan Hadis Pada Masa Tabi'in}

Sebenarnya pada masa khalifah Mu'awiyah, kebijakan tiga khalifah pertama terkait hadis masih terus berlanjut. Pro dan kontra terkait bolehnya penulisan hadis masih berjalan hingga masa Tabi'in. Di antara Kibar Tabi'in yang melarang penulisan hadis adalah 'Ubaidah bin 'Amr al-Salmani' al-Muradi' (w. $72 \mathrm{H}$ ), Ibrahim bin Yazid al-Tami`mi` (w. $92 \mathrm{H}$ ), Jabir bin Zaid (w. $93 \mathrm{H}$ ), dan Ibrahim al-Nakha'i (w. 96 H). ${ }^{36}$ Sedangkan mereka yang pro di antaranya adalah: Sa'id bin Zubair $(95 \mathrm{H})$, Sa'id bin al-Musayyab (w. $94 \mathrm{H}$ ), Abdurrahman bin Harmalah, dan 'Umar bin 'Abd al'Aziz(61-110 H). ${ }^{37}$

Kemudian pada tahun $9 \mathrm{H}$, ketika 'Umar bin 'Abd al'Azizmenjadi khalifah, ia memiliki terobosan baru dalam mengelola hadis-hadis Nabi saw. Ia menginginkan penulisan hadis Nabi Saw. dilanjutkan dengan alasan khawatir akan hilangnya sunnah-sunnah dan hadis Nabi saw. Ia memerintahkan bawahannya yang bernama Abu Bakr bin Muhammad bin 'Amr bin Hazm al-Ansari yang tinggal di Madinah untuk melakukan penulisan hadis. ${ }^{38}$ Beberapa sejarawan juga menyatakan bahwa 'Umar bin 'Abd al-'Azizjuga mengeluarkan perintah penulisan hadis kepada Ibnu Syahab Zuhri dan para pemimpin provinsi lainnya. ${ }^{39}$

Menurut Ibn Hajar al-'Asqallani, begitu juga dengan pandangan ulama kontemporer, perintah 'Umar bin 'Abd al'Aziztersebut menandai permulaan penulisan hadis secara resmi. Perintah tersebut menjadi titik-balik perjalanan penulisan hadis, karena setelah perintah tersebut, secara bertahap ulama-ulama Islam mulai menulis hadis.

Di era Bani Umayyah, usaha penulisan hadis berjalan sangat lambat. Hal ini dikarenakan penulisan dan pembukuan ilmu pengetahuan, menurut mayoritas ulama pada masa itu tidak dianggap sebagai sebuah hal yang menyenangkan. Di sisi lain,

${ }^{36}$ Ajaj al-Khatib, Hadis Nabi..., h. 364.

${ }^{37}$ Ibid., h. 366-369.

${ }^{38}$ Al-Dārimi, Sunan al-Dārimi..., h. 126.

${ }^{39}$ Yusuf bin 'Abdullah al-Namri al-Qurthubi, Jami' al-bayāan al-'Ilm wa Fadlih wa Mā Yanbagī fì Riwāyatih wa Hamlih (Saudi 'Arabia: Dār Ibn al-Jauzy, 1994 M/1414 H), h. 127. 
pembukuan hadis pada masa itu juga masih sangat mendasar sehingga belum tampak kerapihan dan klasifikasi pembahasan yang jelas. $^{40}$

Setelah masa dinasti Bani 'Abbasiyah, terutama pada zaman Mansur al-'Abbasi, terjadi dinamika pembukuan hadis. Menurut alZahabi, pada tahun $143 \mathrm{H}$, ulama-ulama diseluruh kota melakukan pembukuan ilmu-ilmu mereka dalam berbagai bidang seperti hadis, fiqih dan tafsir. Hal ini menghasilkan kemunculan bermacammacam karya dalam bidang keilmuan. ${ }^{41}$

Pada abad ke-2 hingga abad ke-5, pembukuan hadis menemui bentuk khususnya. Hal ini dibuktikan dengan munculnya berbagai metode pembukuan hadis sebagai berikut:

1. Pembukuan hadis secara tematik, khususnya berdasarkan babbab fiqih

2. Pembukuan hadis berdasarkan musnad-musnad, yaitu penulisan hadis tersusun lewat riwayat masing-masing sahabat ${ }^{42}$

Di antara dua metode ini, metode pertamalah yang paling unggul. ${ }^{43}$ d. Tahapan Pembukuan Hadis

Perjalanan pembukuan hadis dalam pandangan Ahlus Sunnah melalui beberapa tahapan penting. Berikut pembagiannya:

1. Periode Tashnif Pertama

Pada periode ini, para muhaddis mencatat hadis-hadis dan non-hadis (baik pendapat para sahabat maupun Tabi'in) dalam kitab-kitab mereka. Pada periode ini tidak terdapat sensitifitas serius terhadap status riwayat-riwayat, apakah ia sahih, saqim, mursal atau musnad. Banyak tokoh hadis terkenal pada abad kedua yang memiliki tashnif ini seperti Ibnu Juraij, Sa'id bin Abi 'Urubah, Hammad bin Salamah, Auza'i, Sufyan al-Sauri, dan Malik bin

${ }^{40}$ Shubhi Shalih, 'Ulum al-Hadis wa Musțalāhuh: 'Arḍ wa Dirāsah (Dār al-'Ilm li al-Malayin, 1984), h. 40.

${ }^{41}$ Mahmud Abu Rayyah, Adwa' 'Alā al-Sunnah al-Muhammadiyyah aw Difa' 'an al-Hadis (Dār al-Ma'arif), h. 264-265.

42 Ibn Șalah, Muqaddimah Ibn Șālah (Beirut: Dār al-Fikr al-Mu'asir, 1986M/1406 H), h. 154.

${ }^{43}$ Abdurrahman bin Abi Bakr Jalaluddin al-Suyuti, Tadrib ..., h. 140. 
Anas. ${ }^{44}$ Meskipun tidak ada karya yang tersisa selain milik Malik bin Anas, yaitu kitab Muwaththa'.

2. Periode Pembukuan Musnad

Musnad adalah kitab yang memuat hadis-hadis berdasarkan urutan nama-nama perawi (sahabat). Pembukuan musnad dimulai pada dekade terakhir abad ke-II dan berlanjut meluas pada abad keIII hingga setelahnya. ${ }^{45}$

Keistimewaan musnad ini adalah terpisahnya hadis Nabi saw. dengan perkataan-perkataan para sahabat dan Tabi'in, serta adanya penjelasan dari para fuqaha tentangnya. ${ }^{46}$ Karena tujuan penulis musnad adalah mengumpulkan riwayat-riwayat yang datang dari para sahabat, wajar bila segala jenis riwayat yang sahih, dha' if dan bahan ja'li terkumpul menjadi satu. Oleh karena itu, jika dilihat dari segi validitas, musnad berada diperingkat ketiga setelah kitab hadis sahih dan sunan. Hanya Musnad Ahmad bin Hanbal saja yang dianggap sejajar dengan kitab sunan. ${ }^{47}$

3. Pembukuan Shihah dan Sunan

Keterbatasan-keterbatasan musnad pada abad ketiga telah melahirkan metode lain dalam proses pembukuan hadis. Metode ini berusaha mengklasifikasi riwayat-riwayat yang sahih dari riwayatriwayat yang lain ke dalam bab-bab yang tematis. ${ }^{48}$

Kemudian pembukuan hadis dengan menggunakan metode sunan juga mulai diminati oleh para muhaddits. Sunan adalah kitab yang biasanya mencakup hadis-hadis ahkam (hukum-hukum fiqih) dan dibukukan berdasarkan bab-bab fiqih. Riwayat-riwayat di dalamnya berbentuk musnad yang non-mauquf. ${ }^{49}$ Karena mauquf

${ }^{44}$ Abdurrahman bin Abu Bakr Jalaluddin al-Suyuti, Tārīkh al-Khulafa' (Mesir: Maṭba'ah al-Sa'adah, 1371 H/1952 M), h. 261.

${ }^{45}$ Muhammad bin Ja'far al-Kattani, al-Risālah al-Mustatarifah: Maktabah al-Kulliyyah al-Azhariyyah (Dār al-Basya'ir al-Islamiyyah, 1993M/1414 H), h. 52-64.

${ }^{46}$ Mahmud Abu Rayyah, Adwa 'alā..., h. 267.

${ }^{47}$ Subhi Salih, 'Ulum al-Hadiṡ wā Mustalāhuh ..., h.297.

${ }^{48}$ Lihat misalnya kitab Sahih Bukhari dan Sahih Muslim.

${ }^{49}$ Nuruddin 'Itr, Manhaj al-Naqd fì 'Ulum al-Hadis (Damaskus: Dār alFikr, 1981 M/1401 H), h. 199. 
hanya disandarkan kepada para sahabat, maka ia tidak disebut dengan sunan (sunnah) Nabi saw.

Di era mutaqaddimin Ahlus Sunnah, pembukuan sunan adalah merupakan hal yang sangat populer. Kitab Sahihain dan Sunan Arba'ah menjadi bagian penting dalam tradisi pembukuan hadis mereka. Kitab Șaḥihain dan Sunan Arba'ah ini disebut dengan Kutub al-Sittah. Kitab-kitab ini semuanya dibukukan pada abad ketiga. Oleh karena itu, abad ini juga disebut dengan abad keemasan pembukuan hadis oleh Ahlus Sunnah. ${ }^{50}$

4. Pembukuan Pasca Kutub al-Sittah

Para muhaddits di abad ke-IV dan ke-V mulai membukukan hadis-hadis yang jarang diperhatikan oleh para muhaddtis sebelumnya dalam bentuk karangan baru. Para muhaddits ternama pada abad tersebut di antaranya adalah:

a. Ibn Hibban (w. $354 \mathrm{H}$ ), penulis al-Musnad al-Sahih atau alAnwa' wa al-Taqasim

b. Abu al-Qasim Sulaiman bin Ahmad al-Thabrani (w. 360 H), penulis tiga mu'jam

c. Al-Daruquthni, penulis Ilzamat (mustadrak sahihain)

d. Hakim al-Naisaburi (w. $405 \mathrm{H}$ ), penulis kitab al-'Ilal, al'Amālì, Fawaid al-Syuyukh, 'Amāli al-'Asyiyyat, Ma 'rifāt 'Ulüm al-Hadis, dan al-Mustadrak 'ala al-Sahihain

e. Baihaqi (w.458 H), penulis kitab al-Sunan al-Kubra dan alSunan al-Shugra. ${ }^{51}$

Hakim al-Naisabury menulis al-Mustadrak 'alā al-Sahīhain adalah sebagai pelengkap bagi Sahih al-Bukhari dan Sahih Muslim yang berdasarkan standar-standar keduanya. Abad ke-V merupakan akhir periode pembukuan hadis era mutaqaddimin menurut Ahlus Sunnah.

${ }^{50}$ Mahmud Fakhuri, al-Imam Muslim bin al-Hajjaj al-Qusyairi alNisaburi (Kairo: Dār al-Salām, 1405 H/1985 M), h. 25.

${ }^{51} \mathrm{Abu}$ Zahu, al-Hadis wa al-Muhaddisun aw 'Inayah al-Ummah alIslamiyyah bi al-Sunnah al-Nabawiyah (al-Risa'ah al-'Ammah, 1404 M/1984 H), h. 407-409. 
5. Pembukuan Jawami' Hadis Era Mutaakhkhir

Yang dimaksud dengan jawami' di sini adalah kitab-kitab yang dibukukan dengan memanfaatkan kitab-kitab utama hadis, seperti Kutub al-Sittah, Muwata' Malik, dan Musnad Ahmad bin Hanbal. Kitab-kitab Jawami' ini dibagi kepada kepada beberapa kategori:

Kitab-kitab yang hanya mengumpulkan riwayat-riwayat sahihain saja. Orang-orang yang melakukan ini adalah:

a. Jauzqi Neisyaburi (w. $388 \mathrm{H}$ )

b. Abu Mas'ud Ibrahim bin 'Ubaid Dimisyqi (w. $401 \mathrm{H}$ )

c. Ibn Furat Sarkhesyi Nisyaburi (w. 414)

d. Abu Bakar Ahmad bin Muhammad Barqani (w. $425 \mathrm{H}$ )

e. Muhammad bin Nasr atau Abu Nasr Futuh Humaidi (w. 488)

f. Husain bin Mas'ud Bagawi (w. $516 \mathrm{H}$ )

g. Muhammad bin 'Abdul Haq Asbili (w. $581 \mathrm{H}$ )

h. Ahmad bin Muhammad Qurtubi, dikenal juga dengan Ibnu Abil Hujjah (w. 642 H) dan Sagani (w. 650 H)

Sedangkan mereka yang melakukannya di era kontemporer adalah di antaranya:

a. Muhammad Habibullah al-Syanqiti (w.1363 H) dalam kitab Zad al-Muslim Fi Ma Ittafaqa 'Alaihi al-Bukhari wan Muslim

b. Muhammad Fuad 'Abd al-Baqi' (w. 1388 H) dalam kitab alLu'lu' wa al-Marjan Fi Ma Ittafaqa 'Alaihi al-Sahihain ${ }^{52}$

Kitab-kitab yang Mengumpulkan Riwayat-riwayat Sihah, Sunan dan Musnad yang Penting

a. Bagawi, penulis Masabih al-Sunnah, yang mengumpulkan riwayat-riwayat Kutub al-Sittah dan Muwatta' Malik bin Anas $^{53}$

b. Ahmad bin Razin bin Muawiyah, penulis al-Tajrid alS\{ihah wa al-Sunan. Ia hanya mengumpulkan riwayatriwayat yang sahih dari Kutub al-Sittah dengan perbedaan

${ }^{52}$ Ibid., h. 430-433.

${ }^{53}$ Ibid., h. 431. 
bahwa ia menggantikan Sunan Ibn Majah dengan Muwatta' milik Malik bin Anas ${ }^{54}$

c. Ibn Atsir Jazri (w. 606 H), penulis Jami' al-Usul min Ahadis al-Rasul

d. Abul Faraj 'Abdurrahman bin 'Ali Jauzi, atau yang dikenal dengan Ibnu Jauzi (w. 597 H), penulis Jami' al-Masanid wa $a l-A l q a b$. Ia mengumpulkan riwayat-riwayat sahihain, Musnad Ahmad bin Hanbal, dan Jami' Tirmizi sesuai urutan musnad-musnadnya. Setelah itu, Muhibbuddin Tabari (w. $694 \mathrm{H})$ memberikan urutan baru dan tadwin (penulisan) baru. ${ }^{55}$

e. Isma'il bin 'Umar bin Kasir atau yang dikenal dengan Ibn Kasir Dimisyqi (w. 744 H), penulis Jami' al-Masanid wa alSunan al-Hadi li Aqwam al-Sunan. Ia mengumpulkan riwayat-riwayat Kutub al-Sittah, Musnad Ahmad bin Hanbal, Musnad Abu Bakar Bazzaz, Musnad Abu Ya'la dan al-Mu'jam al-Kabir Tabrabi. Kitab ini mengandung sekitar seratus ribu hadis dan mencakup riwayat-riwayat sahih, hasan, dan ${ }^{\prime} a^{\prime} i f^{6}$

f. Abdurrahman bin Abi Bakr Jalaluddin al-Suyuti, penulis Jam' al-Jawami' atau Jami' Kabir

g. Muttaqi Hindi, penulis Kanz al-'Ummāl fì Sunān al'Aqwāl wa al-Af'āl, menggunakan metode Suyuti tersebut dengan perbedaan bahwa riwayat-riwayatnya disusun berdasarkan huruf alfabet (arab) dan bertemakan fiqih. Muttaqi Hindi menyusun hadis-hadis al-Jami' al-Sagir dengan metode di atas dan menamakannya dengan Manhaj al-'Ummāl fi Sunan al-Aqwal. ${ }^{57}$

h. Syeikh Mansur 'Ali Nasif (kontemporer), penulis al-Taj alJami' li al-Ushul fi Ahadis al-Rasul mengumpulkan riwayat-

${ }^{54}$ Muhammad bin Ja'far al-Kattani, al-Risalah al-Mustatrifah, h.142.

${ }^{55} \mathrm{Abu}$ Zahu, al-Hadis wa al-Muhaddisun..., h. 431. Lihat juga Muhammad bin Ja'far al-Kattani, al-Risalah al-Mustahrifah..., h. 132.

${ }^{56}$ Muhammad bin Ja'far, al- al-Risalah al-Mustatrifah..., h. 169.

${ }^{57} \mathrm{Abu}$ Zahu, al-Hadis wa al-Muhaddisun ..., h. 446. 
riwayat Kutub al-Khamsah dengan meninggalkan Sunan Ibn Majh.

i. Basysyar 'Awwad Iraqi dan kawan-kawannya mengumpulkan 17.802 hadis dari 1.237 sahabat.

Kitab-kitab yang Hanya Mengumpulkan Riwayat-riwayat Fiqh

a. Al-Sunān al-Kubrā dan al-Sunān al-Sugrā, karya Ahmad bin Husain al-Baihaqi (w. $458 \mathrm{H}$ )

b. Al-Ahkām al-Sughrā karangan Abu Muhammad 'Abd alHaqq 'Isybili (w. $582 \mathrm{H}$ )

c. 'Umdāh al-Ahkām karya al-Hafiz 'Abd al-Gani bin 'Abd alWahid Muqaddasi (w. $600 \mathrm{H}$ )

d. Muntaqā al-Akhbār fi al-Ahkām karya 'Abdu al-Salam bin 'Abdullah Harrani, yang dikenal juga dengan Ibn Taimiyyah (w. $652 \mathrm{H}$ )

e. Al-Targīb wā al-Tarhīìb karya 'Abd al-'zim bin 'Abd alQawi (w. $656 \mathrm{H})$

f. Al-Ilmām fì Ahadis al-Ahkām karangan Ibn Daqiq al-'Aid (w. $702 \mathrm{H}$ )

g. Taqrib al-Asānid wā Tartīb al-Masānid karya Zainuddin Abu al-Fadl 'Abdurrahman bin Husain 'Iraqi (w. $806 \mathrm{H}$ )

h. Bulug al-Marām min Ahadis al-Ahkām karya Ibn Hajr alAsqallani. ${ }^{58}$

Selain yang disebutkan di atas, pada periode mutaakkhir, kitab-kitab hadis yang lainnya juga dibukukan dengan berbagai kekhususan yang berbeda dengan sebelumnya, seperti Kitab Zawāid, Mustakhrajāt Ajza', Atrāf Hadīs, Takhrīj, Ma'ājim baik yang tematis maupun yang berkata, baik kritik maupun tashih terhadap sumber-sumber sebelumnya, baik telaah dari sisi kebenaran sanad maupun matannya, baik hadis maj'ul, maudu', ataupun yang lainnya.

Tradisi penulisan hadis yang beragam ini terus berjalan hingga sekarang. Telaah-telaah hadis yang dilakukan dengan melihat berbagai isu dan topik yang menarik untuk dibahas terus berkembang, baik menjawab pertanyaan-pertanyaan yang kritis

${ }^{58}$ Ibid., h. 432-433, 446-447. 
maupun memenuhi kebutuhan-kebutuhan ilmiah sesuai konteks zaman.

\section{Menurut Perspektif Literatur Syi'ah}

Sebagaimana yang kita ketahui bahwa yang dimaksud dengan hadis Syi'ah adalah berarti hadis-hadis yang disampaikan oleh Nabi Saw. dan oleh para Imam-imam Syi'ah. Para Imam, sebagai pengganti Nabi Saw., telah memiliki dua keistemewaan, yaitu warisan ilmu dan 'ismah. Ucapan yang keluar dari lisan mereka memiliki validitas (kesahihan) sebagaimana ucapan dan perbuatan Nabi Saw. ${ }^{59}$ Hal ini dikarenakan, menurut mereka, karena Nabi Saw. telah berwasiat (baca: bersabda) kepada umatnya untuk selalu berpegang teguh dengan al-Kitab dan juga Ahlul bait (keturunan Nabi Saw atau para imam), karena mereka merupakan salah satu faktor yang akan menyelamatkan umat dari kesesatan. ${ }^{60}$ Karena itu pulalah hujjah-hujjah yang keluar dari lisan mereka menjadi sah untuk dirujuk oleh kalangan Syi'ah. Maka selain mencatat riwayat-riwayat yang datang dari Nabi, mereka juga mencatat hadis-hadis yang disampaikan oleh para Imam mereka.

Sikap Syi' ah sejak awal telah membolehkan penulisan hadis sebagai landasan bagi pembukuan hadis mereka. Berbeda dengan kalangan Ahli Sunnah yang berpendapat bahwa hadis Nabi baru ditulis pada permulaan abad kedua Hijriah atas perintah Khalifah Umar bin 'Abdu al-'Azizkepada salah seorang pembantunya di Madinah, Abu Bakar Muhammad bin 'Amr bin Hazm, dalam ucapannya yang terkenal:

${ }^{59}$ Q.S. al-Ahzab (33): 31, al-Waqi'ah (96): 79.

${ }^{60}$ Hadis yang disabdakan oleh Nabi ini biasa disebut juga dengan istilah hadis Tsaqalain, yang artinya secara bahasa adalah dua bekal berat. Hadis ini sangat masyhur dan mutawatir Dāri Nabi Muhammad Saw., yang bunyi terjemahnya adalah sebagai berikut: "Sesungguhnya ku tinggalkan dua pusaka bagi kalian, yaitu itab Allah dan 'Itrah-ku (Ahli Bait). Keduanya tidak akan terpisah sampai hari kiamat." Hadis ini menjadi rujukan utama kalangan Syi'ah untuk menguatkan doktrin mereka tentang pentingnya ke"imamah"an, menguatkan dalil kemaksuman para Imam a.s. dan juga sebagai dalil yang menurut mereka menetapkan keharusan adanya Imam di setiap zaman. Lihat Abdul Husain Syarafuddin, Al-Muraja 'at (Beirut: 1982M/1402H), h. 72-75; Abul Qasim Khu'i, al-Bayān fì Tafsìr al-Qur'an (Beirut: 1987M/1408H), h. 499. 
انظر ما كان من حديث رسول الله أو سنته فاكتبه, فإني خفت دروس العلم و ذهاب العلماء

"Lihatlah hadis-hadis Rasulullah dan sunnahnya, kemudian tulislah, karena aku khawatir akan hilangnya ilmu dengan perginya para ulama." 61

Padahal, menurut Syi'ah, Nabi Saw. telah mendiktekan beberapa hadis kepada 'Ali bin Abi Thalib a.s. selama beliau masih hidup. Terkadang beliau memberikan tulisan kepada Fathimah sebagai sesuatu yang berguna baginya. ${ }^{62}$ Imam 'Ali a.s. adalah salah seorang penulis Nabi Saw. yang disamping menulis al-Qur'an, beliau juga menulis surat-surat perjanjian Nabi Saw. Mengutip riwayat Suyuți, beliau Saw. juga menganjurkan untuk menulis hadis, terutama dengan sanadnya. ${ }^{63}$ Imam 'Ali juga memiliki beberapa orang penulis (katib), seperti 'Ali dan 'Ubaidillah bin Abu Rafi'. Bahkan menurut Ibnu Nadim, terdapat beberapa dokumen dengan tulisan tangan Imam 'Ali, Imam Hasan dan Imam Husain a.s. ${ }^{64}$ Dengan alasan-alasan tersebut, ketika para ulama menyebutkan perbedaan pendapat sahabat Nabi terkait penulisan hadis, mereka biasanya hanya menyebut nama Imam 'Ali dan Hasan dalam kelompok orang yang menyetujui penulisan hadis. ${ }^{65}$

Kelompok Syi'ah membagi tahapan-tahapan penulisan hadis sesuai sejarah adalah sebagai berikut:

a. Penulisan Masa Nabi

Nabi Saw. pada masa hidup beliau telah mendiktekan tulisan kepada 'Ali bin Abi Thalib. Tulisan ini dikenal oleh kaum Syi'ah sebagai kitab yang pertama dalam Islam. Kitab tersebut dinamakan dengan "Sahifah Jami' ah" atau "Jami" ah,"66 salah satu kitab utama

${ }^{61}$ Sahih al-Bukhari, Kitab al-'Ilm.

${ }^{62}$ Muhammad bin Ya'qub Al-Kulaini, al-Kāfì, j. 2 (Iran: Dār al-Kutub al-'Islamiyyah, 1363), h. 667.

${ }^{63}$ Ganim Qadduri al-Hamd, Rasm al-Muṣhaf: Dirāsah Lugawiyyah Tārikhiyyah (Bagdad: 1982 M/1402 H), h. 96.

${ }^{64}$ Muhammad bin Hasan Tusi, Rijāl al-Țūshi (Najaf: 1961M/1380H), h. 746.

${ }^{65}$ Ibnu Salah, Muqaddimah Ibn Salāh fì 'Ulum al-Hadis (Beirut: 1995M/1416H), 119. Lihat juga Abdurrahman bin Abi Bakr Suyuṭi, Tadrīb alRāwī fì Syarh Taqrīb al-Nāwawī (Beirut: 1989H/1409M), h. 61.

${ }^{66}$ Murtadha Askarī, Ma'ālim al-Madrasatain (Tehran: 1413H), h. 316322. 
hadis Syi'ah yang menunjukkan kesesuaian dengan hadis Nabi Saw. dan kecakapan para Imam sebagai para pewaris ilmu Nabi Saw. Dalam riwayat Ahlu Sunnah sendiri terdapat topik "Sahifah 'Ali". Sahifah ini mencakup beberapa bahasan hukum fiqih seperti diyah, pembebasan budak, dan tidak diperbolehkannya membunuh seorang mukmin dihadapan orang kafir. ${ }^{67}$

b. Pembukuan Usul Hadis

Ushul hadis ini merupakan fitur utama dasar-dasar hadis Syi'ah. Menurut istilah para ahli hadis Syi'ah, “Asl” yang jamaknya adalah "Usul" adalah salah satu jenis kitab hadis. Meskipun terdapat perbedaan pendapat dalam definisinya, akan tetapi "usul" ini biasanya biasanya digunakan sebagai lawan "kitab" atau "tasnif". ${ }^{6}$

Usul hadis disusun oleh sahabat-sahabat para Imam a.s. Dengan adanya dorongan untuk menulis hadis ditambah dengan banyaknya jumlah sahabat para Imam, maka usul yang dibukukanpun sangat banyak jumlahnya. Usul ini disebut dengan "Usul Arba'miah" (Kitab Usul 400) dikarenakan perkiraan jumlahnya yang mencapai 400, atau juga karena alasan lain. ${ }^{69}$ Usul Arba'miah ini banyak dibukukan oleh murid-murid Imam Baqir, Imam Shadiq, dan Imam Kadzim a.s. ${ }^{70}$ Usul Arba'miah ini kemudian menjadi dasar kitab-kitab hadis Syi'ah sejak abad ke-3 dan seterusnya. "Kutub Arba'ah" (istilah kitab hadis Syi'ah yang lain) dan seluruh karya hadis mutaqaddimin lahir dari Usul Arba'umiah ini.

${ }^{67}$ Muhammad bin Idris al-Syāfi'̄̄, Ikhtilāf al-Hadis (Beirut: 1986M/1406H), h. 221. Lihat datanya di Muhammad bin Isma'il al-Bukharī, Sahịh Bukharī, j. 1 (Istanbul: 1981M/1401H), h. 36; Ibnu Hanbal, Musnad alImam Ahmad bin Hanbal, j. 1 (Beirut: Offset Press), h. 79, 81, 100, 102, 110 dan j. 2, h. 35, 121.

${ }^{68} \mathrm{As} l$ yaitu sebuah kitab yang berisi kumpulan riwayat-riwayat yang telah didengar dari para Imam yang maksum atau dari periwayatnya. Sedangkan tashnif adalah hasil kodifikasi para sahabat para Imam dalam mengutip hadis dengan maksud tertentu. Untuk lebih jelasnya silahkan lihat Khomeini, Kitab al-Ṭahärah, j. 3, h. 243-244, 258-262. Lihat Ja'far Subhani, Kulliyah fi 'Ilm al-Rijāl (Qom: Nasyr Islami, 1423H), h. 475, 477.

${ }^{69}$ Zainuddin bin 'Ali Syahid Sani, al-Ri'āyah fi 'Ilm al-Dirāyah (Qom: 1408).

${ }^{70}$ Al-Ṭuhrany, al-Żarī'ah, j. 2 (Beirut: Dār al-Aḍwa, 1403H), h. 125, 147. 
Pasca Penyusunan Kutub Arba'ah, motivasi para ulamamenurut kalangan Syi'ah-untuk mentraskrip usul ini mulai berkurang. Di samping itu pula, sebagian usul telah lenyap karena peristiwa pembakaran perpustakaan Karkh Bagdad yang terjadi pada tahun $477 \mathrm{H}^{71}$

Berdasarkan bukti-bukti yang ada, ${ }^{72}$ usul hadis dari sisi volume dan jumlah hadisnya relatif terbatas dan tidak dapat dibandingkan dengan kitab-kitab yang ada pada masa-masa setelahnya. Di samping itu, usul tersebut juga belum tersusun perbab. Hal itu dikarenakan perhatian para perawinya lebih tertuju kepada pencatatan riwayatnya saja. Dan biasanya usul dikenal dengan nama-nama penulisnya sebagai berikut: Asl Asim bin Humaid dan Asl Hafs bin Suqah. ${ }^{73}$

c. Pembukuan Hadis Abad ke-3

Pasca wafatnya Imam Ja'far Sadiq pada tahu $148 \mathrm{H}$, mayoritas para Imam Syi'ah berpindah dari Madinah ke Irak. Hal ini mengakibatkan terbatasnya hubungan kaum Syi'ah dengan para Imam. Untuk mengatasi permasalahan keagamaan, kaum Syi'ah mengandalkan para ahli hadis di kalangan mereka. Ratusan murid Imam Shadiq pada masa itu menukil dan menyebarkan hadis di berbagai pusat keilmuan. Rata-rata ribuan hadis yang tidak ber-bab ada pada mereka. ${ }^{74}$ Untuk pertama kalinya sebagian murid Imam Sadiq dan Imam Kazim a.s. seperti Hariz bin 'Abdullah Sajistan, Mu'awiyah bin 'Ammar, dan Mu'awiyah bin Wahab menulis beberapa kitab tentang shalat, zakat, puasa, haji dan keutamaannya pada masa itu dengan memanfaatkan riwayat-riwayat yang mereka miliki. $^{75}$

71 Yaqut Hamawi, Mu'jam al-Buldān, j. 1 (Beirut: Dār al-Kutub alIlmiah), h. 799.

${ }^{72}$ Ahmad bin 'Ali al-Najasyi, Rijāl al-Najāsȳ̄ (Qom: Jima'ah alMuDārrisin), h. 134-135.

${ }^{73}$ Al-Thuhrani, al-Dzāri'ah ilā Tasānif al-Syi'ah j.1 (Dār al-Aḍ̂a li alTaba'ah, 1983 M), h. 125-147.

${ }^{74} \mathrm{Ahmad}$ bin 'Ali al-Najasyi, Rijāl al-Najasyī..., h. 40.

${ }^{75}$ Ibid., 144-145. Lihat juga Muhammad bin Hasan Tusi, al-Fihris (Qom: Najaf Offset Press, 1351H), h. 62-63. 
Pada abad ke-3 ini, diawali sejak masa Imam Rida a.s., klasifikasi riwayat-riwayat yang ditulis sesuai dengan berbagai topik fiqih, teologi, dan akhlak. Penulisan masa ini berjalan dengan cepat dan mengalami kemajuan pesat. Para pemukanya merupakan generasi ketiga dari ashab ijma, ${ }^{76}$ Di antara tokoh pada masa itu adalah Hasan bin Sa'id Ahwazi dan saudaranya Husain, dan Ali bin Mahziyar Ahwazi. Dua bersaudara ini secara bersamaan menulis 30 kitab yang masing-masing kitab tersebut menjadi kitab jami' riwayat dalam kitab khusus. Selain mereka yang juga menulis 30 kitab adalah Ibnu Mahziyar. ${ }^{77}$

Dengan dibatasinya ruang gerak para Imam pada masa itu, tokoh-tokoh hadis dari kalangan mereka hanya bisa beraktifitas di masjid-masjid dan hauzah-hauzah (pusat ilmu agama versi Syi'ah). Di samping menulis hadis, para ahli hadis tersebut juga menyiapkan katalog kitab-kitab hadis, terutama kitab-kitab yang mereka peroleh melalui sima' dan qiraah. ${ }^{78}$

Kitab-kitab hadis di atas menginspirasi munculnya kitabkitab hadis yang lebih besar di kalangan mereka pada abad ke-2 dan ke-5 H. Syeikh Saduq sendiri mengakui bahwa banyak kitab mutaqaddimin yang menjadi referensi kitab "Man Là Yahduruh alFāqīh. "79 Demikian pula dengan Syeikh al-Tusi dalam al-Fihrisnya. Masyikhah Tahzib al-Ahkam dan Najasyi dalam kitab rijal-nya juga menyebutkan jalur mereka hingga ke penulis-penulis usul dan musannafat. Namun saat ini kitab-kitab tersebut sudah tidak ada lagi kecuali sedikit yang masih bisa ditemukan, yaitu Mahasin Barqi. ${ }^{80}$

Sejak masa Imam Sadiq a.s. dan setelahnya, sekelompok orang ditunjuk menjadi wakil (perantara) antara Imam Syi'ah dan kelompoknya untuk mengumpulkan pertanyaan-pertanyaan sekitar

${ }^{76}$ Muhammad bin Hasan al-Tusi, Ikhtiyār Ma'rifah al-Rijāl (Masydad, 1348H), h. 556.

${ }^{77}$ Ahmad bin 'Ali al-Najasyi, Rijāl al-Najasȳ̄..., h. 50-60.

${ }^{78}$ Ahmad bin Muhammad Razi, Risālah Abì Galib al-Razì 'ilā Ibn Ibnih fì Zikr 'Alī A'yan wa Takmīlatuhā lì Abì Abdillah al-Gadairi (Qom: 1411H), 160167. Lihat juga misalnya Ibnu Babawaih, Man Lā Yahduruh al-Faqīh, j. 1 (Beirut: 1981M/1401H), h. 4-5.

${ }^{79}$ Ibnu Babawaih, Man Là Yahduruh al-Faqīh..., h. 4-5.

${ }^{80} \mathrm{Ahmad}$ bin 'Ali al-Najasȳ̄, Rijāl al-Najasȳ̄..., h. 76. 
hukum-hukum Islam dari para masyarakat Syi'ah yang akan diserahkan kepada Imam. Para Imam pun memberikan jawaban yang biasanya juga disertai tanda tangan dari mereka. Terkadang para Imam langsung yang mengirimkan surat-surat atau tulisan kepada kaum Syi' ah melalui para wakil perantaranya tersebut untuk menentukan tugas atau menyampaikan taklif bagi mereka dalam menghadapi fenomena-fenomena sosial yang terjadi di sekitar mereka. ${ }^{81}$ Karena tulisan dan jawaban para Imam terhadap pertanyaan-pertanyaan tersebut dianggap hadis atau riwayat, maka para ahli hadis dari kalangan mereka mengumpulkan dan membukukannya hingga muncullah kitab-kitab yang masyhur di kalangan mereka dengan judul "Masā'il" dan "Rasā'il" sebagai refleksi dari hadis-hadis tersebut. ${ }^{82}$

Syeikh Tusi pada saat menjelaskan karya-karya 'Abdullah bin Ja'far Himyari dengan menyebutkan kitab "Masā'il" dan "Tauqi'at". Sedangkan Najazyi menyebutkan ada 3 kitab 'Abdullah tersebut, yaitu sebagai berikut: "Masā’il al-Rijāl wa Mukātabatuhum Aba al-Hasān Al-Sāalis a.s.", "Masā'il Abi Muhammad al-Hasan a.s. 'ala Yad Muhammad bin 'Utsman al'Amri ", dan "Masā'il Abi Muhammad wa Tauqi'at". Selain mereka, yang membukukan "Masā'il" pada periode ini adalah Zakariya bin Adam, Muhammad bin Sulaiman, Harun bin Muslim, Ya'qub bin Yazid, Ya'qub bin Ishaq Sikkit dan Ahmad bin Ishaq Asy'ari. Begitu juga dengan Kulaini yang menulis sebuah kitab yang berjudul "Rasā'il al-A 'immah". ${ }^{83}$

Koleksi Rasā'il dan Masā'il ini masih terjaga hingga abad ke-5 dan menjadi rujukan utama kitab hadis Syi'ah Kutub Arba'ah dan juga kitab-kitab lainnya seperti Usul Riwa'i. Namun semuanya secara bertahap lenyap setelah taqti dan klasifikasi kontennya. ${ }^{84}$

Ibnu Babawaih menyatakan bahwa ia telah memperoleh koleksi surat dan tauqi' at milik Imam Hasan 'Askari a.s. dari tulisan

81 Muhammad Baqir Syarif Quraisȳ̄, Hayah al-Imām al-Hasan al'Askarī (Beirut: 1408H), h. 73-88.

${ }^{82}$ Ibid., h. 73-88.

${ }^{83}$ Ahmad bin 'Ali al-Najasȳi, Rijāl al-Najasȳ̄..., h. 220, 347, 377.

${ }^{84}$ Ibid., h. 220, 347, 377. 
beliau sendiri melalui Abu Ja'far Shaffar. Harun bin Musa Talla'kabari dan juga Ahmad bin Husain bin Abdullah Gadlairi juga melaporkan bahwa mereka melihat banyak surat Imam ke -11 dan 12. ${ }^{85}$ Ibnu Babawaih dan Syeikh Tusi dari Mutaqaddimin, atau Muhammad Baqir Majlisi (w.1110) dari muta'akhhirin juga mengumpulkan berbagai tauqi'at Imam Mahdi a.s.

d. Penulisan Kutub Arba'ah

Sebagaimana halnya Ahli Sunnah, Syi'ah juga tidak luput dari adanya pemalsuan hadis dan distorsi. Hal ini dikarenakan beberapa faktor internal mereka seperti adanya perawi-perawi każab, fasìdu al-mażab, dan majhū al-hāl dan juga faktor eksternal seperti kondisi sosial politik yang dihadapi di masanya atau terputusnya hubungan dengan Imam mereka.

Faktor yang paling utama yang menyebabkan munculnya pemalsuan hadis di kalangan mereka adalah karena adanya pemikiran "gulah" (berlebihan) di kalangan mereka dalam mengkultuskan para Imam. Pemikiran ini muncul sejak masa Imam Ali Zainal Abidin a.s. dan berlanjut hingga akhir masa para Imam. Pada masa setiap Imam tersebut muncul kelompok yang dikenal dengan "gali" (pengkultus). Namun mereka ini pun dilaknat oleh para Imam mereka. ${ }^{86}$ Imam-imam Syi'ah sering menampakkan kebohongan mereka. Seperti halnya yang berkenaan dengan Mughirah bin Sa'id, Imam Sadiq a.s. menyinggung pemalsuan hadis dan penambahan yang dilakukan oleh Mughirah dalam kitabkitab para sahabat ayah beliau, Imam Baqir a.s. Imam Rida juga menyebut Bayan, Mugirah bin Sa'id, Abu al-Khattab dan lainnya sebagai pendusta. ${ }^{87}$ Imam Hasan Askari juga disamping mendustakan akidah 'Ali bin Hasakah dan Qasim Yaqtini, ia juga melaknat mereka. ${ }^{88}$

Pasca periode para Imam, usaha-usaha yang dilakukan tokoh-tokoh Syi'ah adalah mengidentifikasi golongan yang "gulah"

${ }^{85}$ Ahmad bin 'Ali al-Najasȳ̄, Rijāl al-Najasȳ̄..., h. 355, 380.

${ }^{86}$ Muhammad bin Hasan al-Tusi, Ikhtiyār Ma'rifah al-Rijāl..., h. 290291, 295, 300 .

${ }^{87}$ Ibid., h. 302.

${ }^{88}$ Ibid., h. 516-517. Lihat juga Muhammad Baqir al-Majlisi, Bihār alAnwār..., j.25, h. 316 . 
dan menolak klaim mereka sebagai Syi'ah. Meski berbagai upaya telah dilakukan, namun sebagian riwayat palsu dan yang meragukan telah masuk ke dalam koleksi hadis-hadis Syi'ah. Oleh karena itu pula muncul perbedaan dan kontradiksi di dalam internal hadishadis Syi'ah sendiri. ${ }^{89}$

Menurut kalangan Syi'ah, setelah Imam ke-12 ghaib dari dunia dan hubungan para pengikutnya terputus dengan Imam mereka, perbedaan dan kontradiksi hadis-hadis mereka menjadi jelas dan kebenaran hadis mereka menjadi samar bahkan bagi orang yang berilmu. ${ }^{90}$ Sehingga dalam kondisi seperti ini, para ahli hadis mereka pun merasa butuh untuk memurnikan hadis-hadis mereka dan membukukan kembali hadis-hadis yang dapat dipercaya. Pembukuan Kutub Arba'ah oleh Muhammad bin Ya'qub alKulaini, Muhammad bin 'Ali bin Babawaih dan Muhammad bin Hasan Tusi (yang populer dengan tiga nama Muhammad di awal) dan pembukuan karya-karya hadis lainnya, khususnya lagi kitabkitab karangan Ibnu Babawaih dan Syeikh Tusi pada abad ke-4 dan ke-5 adalah merupakan langkah penting dalam upaya mengatasi permasalahan dan pertentangan yang ada di sekitar hadis tersebut. ${ }^{91}$

Dengan disusunnya Kutub Arba'ah dan kitab-kitab hadis lainnya di abad ke-4 dan ke-5, terutama kitab-kitab haids Syeikh Saduq, Seyikh Tusi, Sayed Murtada dan Syeikh Mufid, maka berakhirlah pembukuan hadis Syi'ah di masa mutaqaddimin. Para fuqaha dan mutakallimin di kalangan Syi'ah pun menulis karyakarya fiqih dan teologi dengan merujuk kepada kitab-kitab tersebut.

Di sisi lain, pasang surut kondisi sosial politik Syi'ah telah menghambat proses pembukuan karya-karya mereka yang baru. Para 'ulama Syi'ah lebih memperhatikan penyalinan kitab-kitab yang ada sebelumnya melalui cara ijazah, kitabah, dan wijadah. Meskipun demikian, kajian ilmu hadis dan pembahasan rijal dan

${ }^{89}$ Ahmad bin 'Ali al-Najasyi, Rijāl al-Najasyī..., h.332-338; Muhammad Baqir Behbudi, Ma'rifah al-Hadis wā Tārīkh Nasyrih wa Tadwīnih wa Tsaqāfatih 'ind al-Syi'ah al-Imāmiyyah (Tehran: 1362 HS), h. 47, 44. Lihat juga Muhammad bin Hasan Tusi, Tahì̄b al-Ahkām, j. 1(Beirut: Hasan Musawi Khursan, 1981M/1401M).

${ }^{90}$ Lihat Muhammad bin Ya'qub Al-Kulaini, al-Käfī..., j. 1, 8.

${ }^{91}$ Ibid., h. 8. 
dirayah (yang merupakan ilmu dasar dan penting dalam kajian hadis) juga banyak bermunculan. Tokoh-tokoh seperti Najasyi, Kasyi, Ibnu Gadairi, Ahmad bin Tawus, 'Allamah Hilli dan Ibnu Daud Hilli telah mengambil langkah yang efektif dalam hal ini.

Di antara karya penting studi hadis yang dibukukan oleh kalangan Syi'ah dalam rangka studi kritis terhadap Kutub Arba'ah, terutama dalam hal sanad, kejelian perawi, dan dhabit, adalah kitab Muntaqā al-Jumān fì al-Ahādis al-Sihāh wā al-Hisān. Kitab ini ditulis oleh Hasan bin Zainuddin 'Amili, seorang yang faqih dan ahli ushul ternama, yang juga dikenal dengan penulis Ma'alim. Namun sangat disayangkan bahwa karya tersebut tidak sampai selesai.

\section{e. Pembukuan Hadis Periode Mutaakhkhirin}

Dengan berkuasanya Pemerintahan Syi'ah Syafawi pada abad ke-10, terciptalah ruang baru penyebaran ajaran-ajaran Syi'ah. Banyak 'ulama Syi'ah dari berbagai kita berdatangan ke Iran. Di antaranya adalah Husain bin Abdul Samad, dan puteranya yang bernama Bahauddin Muhammad yang dikenal juga dengan Syeikh Baha'i, dan Muhaqqiq Karaki. Ketiganya berasal dari Jabal Amil. Kemudian ada pula Muhaqqiq Misi dari Irak dan juga Sayed Majid Bahrani dari Bahrain. Hal ini membuat karya-karya Syi'ah di bidang hadis dan fiqih menjadi berjalan lagi setelah beberapa waktu terhenti. ${ }^{92}$

Di sisi lain, setelah Mulla Muhammad Amin Ester abadi menyusun kitab al-Fawā'id al-Madaniyah dan tersebar di Iran dan Irak, beberapa ahli fiqih memiliki orientasi akhbari. Mereka memberikan perhatian dan minat yang banyak terhadap hadis dan ulum-nya. Para ahli hadis paling populer pada masa tersebut adalah yang dikenal dengan "tiga Muhammad awal". Karya-karya para ahli hadis tersebut menjadi sumber inspirasi bagi terciptanya karyakarya penting yang terbaru, yaitu: ${ }^{93}$

${ }^{92}$ http://www.dd-sunnah.net/forum/showthread.php?t=166598, di akses pada tanggal 11 Mei 2018 Dāri makalah Syeikh al-Musnid Muhammad Ziyad alTakleh.

${ }^{93} \mathrm{Hafiz}$ al-Rahman bin Hakim 'Ad al-Jabbar, 'Ulū̄m al-Hadīs bain Ahl al-Sunnāh wa al-Syi'ah al-Imāmiyyah al-Iśn̄a 'Asyariyyah, Seri Disertasi (Pakistan: International Islamic University Islam abad), h. 66. 
1. Al-Wāfi karya Muhammad bin Murtada yang dikenal juga dengan Maula Muhsin Faid Kasyani. Kitab ini adalah koleksi Kutub al-Arba'ah dengan menguhapus pengulanganpengulangannya. Kitab ini mengandung syarh (penjelasan) dan studi hadis.

2. Bihār al-Anwār karya Muhammad Baqir Majlisi. Dilihat dari kontennya, kitab ini mencakup pembahasan keagamaan secara luas. Referensi yang dimuat dalam kitab tersebut lebih dari 360 kitab, risalah hadis, dan lainnya. Kitab in juga disertai syarh dan komentar penulisnya.

3. Wasā'il al-Syi'ah karya Muhammad bin Hasan Syeikh Hur 'Amili (w. 1104). Kitab ini mengumpulkan hadis-hadis fiqih berdasarkan bab-bab yang populer di kalangan fuqaha Syi'ah. Kitab ini juga secara umum berasal dari Kutub Arba'ah dan juga menggunakan referensi-referensi kitab sebelumnya.

4. 'Awālim al-'Ulūm wā al-Ma'ārif wāa al-Ahwāl karya Maula Abdullah Bahrani Isfahani, murid dari Muhammad Baqir Majlisi. Dari segi susunan dan isinya, kitab ini hampir sama dengan Bihar al-Anwar.

Secara umum, pada masa Dinasti Safawi, terlepas dari perhatian para ahli hadis terhadap pencarian dan identifikasi sebagian karya hadis yang ditinggalkan oleh para ulama Syi' ah, atau menjaganya dari kerusakan dan kemusnahan, orientasi perhatian terhadap syarh dan studi hadis juga marak dilakukan. Ulama seprti Mirdamad, Sadrul Muta'allihin Syirazi, Maula Muhammad Taqi Majlisi, Maula Saleh Mazandarani, Muhammad Baqir Majlisi, Maula Rafi' Qazwini, Qadhi Sa'id Qommi dan Sayed Nikmatullah Jazairi menulis syārah terhadap karya-karya hadis mutaqaddimin, terutama Kutūb Arba'ah. Syarh-syarh tersebut mengevaluasi dan menganalisis seluruh isi sanad dan matan hadis. Dan dari sisi topik terkadang juga menggunakan pembahasan dan formasi baru dalam ilmu agama. ${ }^{94}$

Setelah itu, tradisi pembukuan karya-karya baru hadis Syi'ah berlanjut lebih lambat. Beberapa 'ulama melakukan

94 Ayatullah Sayyid Hasan al-Shadr, Peradaban Syi'ah dan Ilmu Keislaman, terj. 'Ammar Fauzi (Majma' Jahani Ahlul Bait, 2007), h. 126-129. 
penulisan mustadrak terhadap kitab-kitab jami' sebelumnya, seperti Bihār al-Anwār dan Wasā'il al-Syi'ah. Mustadrak Wasā'il merupakan kitab yang paling populer yang ditulis oleh Mirza Husain Nuri Mazandarani (w. 320), seorang ahli hadis dan bibliografi terkenal. Kitab ini disusun berdasarkan referensireferensi kitab terdahulu dan beberapa kitab-kitab terbaru di masanya, ditulis berdasarkan urutan bab yang ada di dalam kitab Wasā'il. Saat ini kitab tersebut pun menjadi salah satu kitab paling penting dalam kajian fiqih bagi para mujtahid Syi' ah. ${ }^{95}$

Langkah terakhir dari pembukuan hadis yang dilakukan Syi'ah—selain karya-karya yang bersifat tematis dan terklasifikasi per-bab adalah penulisan Jami' Ahadis al-Syi'ah, pengkoleksian kitab hadis fiqih. Ide ini dilontarkan oleh Ayatullah Husain Taba' taba'i Burujurdi, seorang yang faqih yang terkenal dan menjadi tempat rujukan taqlid Syi'ah. Begitu juga dengan penyusunan mu'jam secara tematis dan perkata yang bertujuan untuk memudahkan pencarian konten (isi) hadis pada kitab-kitab Jami' juga menjadi hal yang populer pada beberapa dekade terakhir ini. karya yang paling populer dalam hal ini adalah kitab Safinah Bihar karya Syeikh 'Abbas yang dikenal dengan Muhaddits Qummi (w. 1359). Kitab ini juga tematis dan berurutan sesuai abjad sebagaimana Bihār al-Anwār. ${ }^{96}$

\section{Kesimpulan}

Perbedaan perumusan perjalanan pembukuan hadis hingga metodologinya antara kelompok Sunni dan Syi'ah adalah sebenarnya - di samping dampak politik yang terjadi antara mereka - karena perbedaan mereka dalam memahami dan menginterpretasi sejarah. Perjalanan sejarah yang mereka temui adalah sama, hanya saja persepsi mereka dalam memahami, menginterpretasi dan menerima sejarah yang berbeda-beda. Kelompok Sunni misalkan menganggap bahwa pembukuan hadis pertama dilakukan oleh 'Umar bin 'Abd al-'Azizyang memerintahkan bawahannya Abu

${ }^{95}$ Ibid., h. 126-129.

96 Untuk lebih lengkapnya lihat Ayatullah Sayyid Hasan 1-Shadr, Peradaban Syi'ah dan Ilmu Keislaman, h. 117-136. 
Bakr bin Muhammad bin 'Amr bin Hazm al-Anshari dan dalam riwayat lain juga menyuruh Ibn Syahab al-Zuhri untuk mengumpulkan hadis demi terjaganya sabda-sabda Rasulullah saw. di muka bumi ini. Menurut orang-orang Sunni, pembukuan hadis belum ada terjadi sebelum masa 'Umar bin 'Abd al-'Aziz. Sebelumnya ada beberapa sahabat yang membukukan hadis namun setelahnya buku-buku tersebut mereka binasakan atau bahkan mereka bakar karena khawatir itu akan mengganggu keotentikan alQur'an. Sementara menurut kelompok Syi'ah, orang yang pertama membukukan hadis adalah 'Ali bin Abi Thalib dan dilanjutkan oleh Ja' far, hingga seterusnya. Menurut mereka, pembukuan hadis malah sebenarnya sudah ada semenjak Rasulullah saw. masih hidup.

Perbedaan ini tentunya terjadi dikarenakan pemahaman dan pengetahuan mereka terhadap sejarah Nabi berbeda-beda. Hingga pada akhirnya kesimpulan yang mereka paparkanpun terkait tahapan perumusan pembukuan hadis ini berbeda-beda. Meski begitu, perbedaan ini mestinya tidak menjadi sebuah fanatisme atau truth claim yang berakibat tidak mau menerima sama sekali pendapat-pendapat kelompok yang berbeda aliran, khususnya dalam kasus di tulisan ini adalah kelompok Sunni dan Syi'ah. Perbedaan itu hendaknya menjadi khazanah pengetahuan baru yang terus digali, dicermati dan dijadikan bahan rujukan untuk pengetahuan yang lebih objektif ke depannya. [ ] 


\section{DAFTAR PUSTAKA}

A'ẓami, Muhammad Mustafa, Dirāsat fì al-Ahādis̀ al-Nabawī wa Tārīkh Tadwīnih, al-Maktab al-Islāmī, 1400 H/1980 M.

Abu Rayyah, Mahmud. Adwa' 'Alā al-Sunnah al-Muhammadiyyāh aw Difä' 'an al-Hadis, tt, Dar al-Ma'arif, tt.

Abu Zahu, Al-Hadis wa al-Muhaddisun aw 'Ināyah al-Ummah alIslāmiyyah bi al-Sunnah al-Nabawiyah, Al-Risālah al'Ammah, $1404 \mathrm{M} / 1984 \mathrm{H}$.

Al-Amin, Muhsin. A 'yān al-Sȳ̄'ah, Dār al-Ta'āruf lī al-Matbu'at, tt. Al-Bagdādi, 'Abd al-Qadir bin 'Umar, Khazānah al-Adab wa Lubb Lubāb Lisān al- 'Arab, Kairo: Maktabah al-Khanizi, 1418 H.

Al-Bagdadi, al-Khatib, Taqyīd al- 'Ilm, Dār al-Istiqamah, 2011.

Al-Bukhari, Muhammad bin Isma'il, Șahih Bukhari, Istanbul: $1981 \mathrm{M} / 1401 \mathrm{H}$.

Al-Darimi, Sunan al-Darimi.

Al-Hamd, Ghanim Qadduri, Rasm al-Mushaf Dirāsah Lugawiyyah Tārīkhiyyah, Bagdad: $1982 \mathrm{M} / 1402 \mathrm{H}$.

Al-Hasyimi, Muhammad bin Sa'd, Tabaqāt Ibn Sa'ad, Beirut: Dar al-Kutub al-'Ilmiah, 1410 H/1990 M.

Al-Husaini, Hasyim Ma'ruf, Dirāsāt fĭ al-Hadis̀ wā al-Muhaddisīn. Beirut: Dar al-Ma'arif.

Al-Jabbar, Hafiz al-Rahman bin Hakim 'Ād, 'Ulūm al-Hadis Baina Ahl al-Sunnah wa al-Syi’ah al-Imāmiyyah al-Iśn̄a 'Asyariyyah, Seri Disertasi, Pakistan: International Islamic University Islam abad, tt.

Al-Kattani, Muhammad bin Ja'far, Al-Risālah al-Mustatrifah: Maktabah al-Kulliyyāh al-Azhariyyah, Dar al-Basyā'ir alIslāmiyyah, 1993M/1414 H.

Al-Khathib, Muhammad 'Ajjaj, al-Sunnah Qabl al-Tadwin, Maktabat Wahbah: 1408 H/1988 M.

, Hadis Nabi Sebelum Dibukukan, trans. AH. Akron Fahmi. Jakarta: Gema Insani Press, 1999. 
Al-Kulaini, Muhammad bin Ya'qūb, Al- Kāfì, Iran: Dār al-Kutub al'Islāmiyyah, 1363.

Al-Majlisi, Muhammad Baqir, Bihār al-Anwār: al-Jāmi'ah li Durari Akhbār al-Aimmah al-Ațar, Beirut: Mansyurāt Muassisah al-A'lamī li al-Matbu'āt, 2008.

Al-Najasyi, Ahmad bin 'Ali, Rijal al-Najasyi, Qom: Jimā'ah alMudarrisin.

Al-Quraisyi, Muhammad Baqir Syarif, Hayah al-Imām al-Hasan al'Askari, Beirut: 1408H.

Al-Qurțubi, Yusuf bin 'Abdullah al-Namri, Jamī' al-Bayān al-'Ilm wā Fadluh wā Mã Yanbagi fì Riwāyatih wā Hamlih, Saudi 'Arabia: Dār Ibn al-Jauzy, 1994 M/1414 H.

Al-Ramahurmuzi, al-Muhaddis al-Fāsil, Naskah Damaskus.

Al-Razi, Ahmad bin Muhammad, Risālah Abi Gālib al-Rāzi ‘ilāibn Ibnih fi Zikr 'Ali A'yan wa Takmilatuha li Abi Abdillah alGadairi, Qom: tp, 1411H.

Al-Sayis, 'Ali, Tarikh al-Fiqh al-Islami, Beirut: Dar al-Kutub alIlmiah, tt.

Al-Ṣadr, Ayatullāh Sayyid Hasan, Peradaban Syi'ah dan Ilmu Keislaman, terj. 'Ammar Fauzi, Majma' Jahanī Ahlul Bait, 2007.

Al-Suyuṭi, Abdurrahman bin Abu Bakr Jalaluddin, Tarikh alKhulafā', Mesir: Maṭba'ah al-Sa'ādah, 1371 H/1952 M. , Tadrib al-Rāwi fì Syarh Taqrīb al-Nawawi, Beirut: Dar al-Fikr, 1988 M/1409 H.

Al-Syafi'i, Muhammad bin Idris, Ikhtilaf al-Hadis, Beirut: 1986M/1406H.

Al-Ṭuhranī, al-Dzari'ah ilā Tasānif al-Syi'ah, Dar al-Adwa li alTabā'ah, 1983 M.

Al-Ṡani, Zainuddin bin 'Alī Syāhid, Al-Ri'àyah fi 'Ilm al-Dirāyah, Qom: tp, 1408.

Askari, Murtadha, Ma 'àlim al-Madrasatain, Tehran: tp, 1413H. 
Behbudi, Muhammad Baqir, Ma'rifah al-Hadīs wa Tärikh Nasyrih wa Tadwīnih wā Śaqafatih 'inda al-Syi'ah al-Imāmiyyah. Tehran: tp, $1362 \mathrm{H}$.

Fakhuri, Mahmud, Al-Imām Muslim bin al-Hajjāj al-Qusyairī alNisāburi, Kairo: Dar al-Salam, 1405 H/1985 M.

Hamawi, Yaqut, Mu ’jam al-Buldān, Beirut: Dār al-Kutub al-Ilmiah.

Ibn Kas̄īr, Al-Bidāyah wā al-Nihāyah, Beirut: Maktabat al-Ma'arif, $1414 \mathrm{H} / 1990 \mathrm{M}$.

Ibn Șalah, Muqaddimah Ibn Șalah, Beirut: Dar al-Fikr al-Mu'asir, $1986 \mathrm{M} / 1406 \mathrm{H}$.

Ibnu Babawaih, Man La Yahduruh al-Faqih, Beirut: 1981M/1401H.

Ibnu Hanbal, Musnad al-Imam Ahmad bin Hanbal, Beirut: Offset Press, tt.

'Itr, Nuruddin, Manhaj al-Naqd fi 'Ulūm al-Hadis, Damaskus: Dār al-Fikr, $1981 \mathrm{M} / 1401 \mathrm{H}$.

Juynboll, G.H.A, Kontroversi Hadis di Mesir, Bandung: Mizan, 1890-1960.

Khomeini, Kitab al-Tahārah, Radmuk, tp, tt.

Khu'i, Abul Qāsim, Al-Bayān fì Tafsīr al-Qur'ān, Beirut: $1987 \mathrm{M} / 1408 \mathrm{H}$.

Kuntowijoyo, Pengantar Ilmu Sejarah, Yogyakarta: Bentang Pustaka, 2005.

Lubis, Herlina, Sejarah Perkembangan Islam di Jawa Barat, Jawa Barat: Yayasan Masyarakat Sejarawan Indonesia, 2011.

Muslim ibn Hajjaj, Sahih Muslim.

Rakhmat, Jalaluddin, Rekayasa Sosial, Bandung: Rosda.

Shalih, Shubhi, 'UlUm al-Hadīs wa Mușțalahuh: 'Arḍ wa Dirāsah, Dār al-'Ilm li al-Malāyin, 1984.

Subhani, Ja'far, Kulliyah fì 'Ilm al-Rijāl, Qom: Nasyr Islāmi, $1423 \mathrm{H}$.

Syarafuddin, Abdul Husain, Al-Muraja'āt, Beirut: 1982M/1402H. 
Tusi, Muhammad bin Hasan, Al-Fihris, Qom: Najaf Offset Press, $1351 \mathrm{H}$.

, Ikhtiyar Ma'rifah al-Rijal, Masydad, tp, 1348H. , Rijal al-Tuși, Najaf: tp, 1961M/1380H. Tahzib al-Ahkam, Beirut: Hasan Musawi Khursan, $1981 \mathrm{M} / 1401 \mathrm{M}$.

'Ulum, Muhammad Babul, Merajut Ukhuwah, Mengenal Syi'ah. Bandung: Penerbit Marja, 1428/2008.

http://www.dd-sunnah.net/forum/showthread.php?t=166598, di akses pada tanggal 11 Mei 2018 dari makalah Syeikh alMusnid Muhammad Ziyad al-Takleh. 